\title{
Evaluation of Banks' Interest Rate Risk: An Alternative Approach
}

\author{
Jakob Lichtner ${ }^{1}$, Marcus Riekeberg ${ }^{2}$, Friedrich Thießen ${ }^{1} \&$ Thomas Maurer $^{1}$ \\ ${ }^{1}$ Chair of Banking and Finance, School of Economics, Chemnitz University, Chemnitz, Germany \\ ${ }^{2}$ Private University Schloss Seeburg, Seekirchen, Austria \\ Correspondence: Friedrich Thießen, Fakultät für Wirtschaftswissenschaften, TU Chemnitz, D-09107 Chemnitz, Germany.
}

Received: September 28, 2018

doi:10.11114/aef.v5i6.3662
Accepted: October 12, $2018 \quad$ Available online: xx, 2018

URL: https://doi.org/10.11114/aef.v5i6.3662

\begin{abstract}
Interest rate risk is often assessed through parallel yield curve shifts of 100, 200 or 400 basis points. In order to provide a more realistic view, we did simulations based on periods of growing interest rates that actually occurred in the past. These simulations show that non-bank deposits and non-bank loans react more strongly to rising interest rates than certain interbank and security positions. Existing research usually overestimates related risks slightly as it does not take the interest-elastic reactions of non-banks into account. We found three types of effects. Firstly, the direct earnings effect stems from changed market interest rates applied to constant balance sheet positions. This effect is typically measured by straightforward models. Secondly, to increase accuracy, we identified an indirect earnings effect. Customers react to interest rate changes, and therefore balance sheet positions increase or decrease. The size of this effect depends on how strongly they react, i. e. their interest elasticity. Thirdly, the induced earnings effect results from a bank's reactions in an attempt to compensate for the changed business volume.
\end{abstract}

Keywords: interest rate risk, one-time interest rate shocks, interest rate risk management, rise in interest rates, interest increase, maturity transformation, savings banks

JEL Classification: C15, G21, G28

\section{Introduction}

The Federal Reserve System (Fed) has recently started to reduce its securities. This may lead to an increase of long-term interest rates and a steepening yield curve. Subsequently, the short-term interest rates may increase as well (Miller, 2017). The Eurozone is currently expecting a major increase of interest rates as well as the European Central Bank (ECB) will proceed with the policy of "Sequencing". "Quantitative Easing" (purchase of securities) is supposed to gradually phase out. However, according to the ECB, the short-term interest rates should remain at record lows for a long time (Wearden, 2018).

Interest rate risk has been thoroughly discussed by both bankers and researchers. Banks have been favoring a slow upward movement of interest rates including a steepening yield curve. This is because a rapid rise would imply high risk for banks, especially if they refinance long-term assets with predominantly short-term liabilities (maturity transformation). To manage related interest rate risks German savings banks use established concepts like the Value-at-Risk approach, duration analysis, interest rate elasticity based concepts and cashflow or financial instruments (e. g. forward rate agreements, interest rate futures, interest rate swaps, interest rate options). Unfortunately, these concepts have limitations. The Value-at-Risk approach only considers the probability and not the size of claim shortfalls, and is not subadditive (Kaas, Goovaerts, Dhaene, \& Denuit, 2008). Duration analysis assumes a parallel shift of the underlying interest rate structure which is not very common to observe (Campbell, Lo, \& MacKinlay, 1997). Interest rate elasticity concepts do not consider recent or future interest rate movements and the cashflow analysis is not perfectly suitable for modeling all bank transactions (Kroon, 2009; Spellmann, 2002).

From a regulatory perspective, interest rate risk management for German savings banks is laid down in national and international legal texts. Relevant articles are contained in the German Banking Act (Kreditwesengesetz), the Minimum Supervisory Requirements to Risk Management (Mindestanforderungen an das Risikomanagement), the Solvency Regulation (Solvabilitätsverordnung) and the Liquidity Regulation (Liquiditätsverordnung). These national regulations cover process-related and system-specific aspects of interest rate risk management, capital requirement, governance standards and strategic aspects. However, they classify interest rate risks as market price risks and do not differentiate 
between banking and trading book. As opposed to that, international regulations, mainly based upon Basel II and III by the Basel Committee on Banking Supervision (BCBS), explicitly distinguish between interest risks in the trading and the banking book. Basel II and III provide quantitative guidelines like capital requirements for managing interest risks in the trading book and only qualitative guidelines like processes for the banking book (Menningen, 2013). As for German savings banks long-term fixed rate loans to customers represent the core business (see also Tables 2 and 3 ), the majority of interest rate risks are in the banking book for which neither national nor international regulations provide quantitative guidelines (Deutsche Bundesbank, 2004).

To assess the risk of increasing interest rates, banks and regulators commonly simulate one-time parallel upshifts of the yield curve by 100, 200 or 400 basis points (bps). This method is also referred to as interest rate shock analysis. We find this analysis unrealistic and incomplete because the mentioned shifts neither reflect historical interest rate movements nor do they represent the expected rise in interest rates. This analysis may therefore not be appropriate for assessing the impact of increasing interest rates on banks' balance sheets, their earnings and regulatory requirements. The first objective of this article is therefore to critically analyze the appropriateness of conventional interest rate shocks in analyzes commonly to assess the interest rate risks for European banks. As banks are looking for an alternative way we secondly propose a more practice-oriented, holistic and methodologically new approach to assess how the expected long-lasting rise in interest rates will influence financial performance and risk of medium-sized savings banks. As this topic has been discussed before, we sum up relevant academic literature, divided into five categories.

The first category comprises literature that describes the basics of interest rate risk, provides a general overview of the fundamental economic effects of changes in interest rates and related rate risk management. As interest rate risks have been intensely discussed in research and business practice, this category contains especially comprehensive textbooks (Coyle, 2001; Cornyn, Klein, \& Ledernan, 2000; Grumball, 1987).

The second category focusses on the management of interest rate risks and includes several textbooks (Zagst, 2002; Nawalkha/Chambers, 1999; Chen, 1996). It focuses specifically on the impact on financial products, their use and banking related key figures (Cornyn, Mays, 1997, pp. 75 ff.; Gup, Brooks, 1993).

The third category analyzes how to use financial instruments to manage interest rate risks and comprises basic literature (Gup \& Brooks, 1993; Stephens, 2002).

The fourth category considers the microeconomic implications of interest rate shocks for an individual bank. Samuelson investigated the impact of rises in interest rates on the performance and success of banks as early as in 1945. Scholz, Simon and Wilkens (2007) analyze banks' stock prices to determine their interest rate risks by using a regression model. They develop a factor for assessing maturity transformation strategies of financial institutions and its contribution to their total return and risk. Memmel (2008) analyzes the impact of 260 historical interest rate scenarios for German savings banks and cooperative banking institutions and focuses on the net interest income and the economic value of these banks. Chaudron (2018) analyzes the development of Dutch banks' interest rate risk positions in the banking book for the 2008 to 2015 period. He finds that interest rate risk is negatively related to on-balance sheet leverage, and that banks which received government assistance during the financial crisis have higher interest rate risks than others. Borio, Gambacorta and Hofmann (2017) investigate how monetary policy affects bank profitability by focusing on 109 large international banks. They identify a positive correlation between the level of short-term rates, the slope of the yield curve and the bank profitability (return on assets). Apart from this, numerous other papers focus only the development of banks' net interest margin and banks' net interest income due to interest rate movements or evaluate short-, medium- and long-term effects of interest changes on these key figures (Busch \& Memmel 2015; English 2002). Furthermore, several articles focus on the profitability of banks depending on the interest rate level and how bank profitability varies with interest rate changes (Alessandri, 2014; Dietrich \& Wanzenried, 2014; Genay \& Podjasek, 2014). Here, Genay and Podjasek (2014) provide interesting insights as their US market research shows that steeper yield curves increase banks' net interest margin and that yield curve changes impact smaller banks more heavily than larger ones.

Finally, the fifth category considers the macroeconomic implications of interest rate changes for the overall banking sector or entire countries. This is being intensively analyzed by supervisory institutions or regulators on a regular basis. Other researchers like Claessens, Coleman and Donnelly (2017) focus on entire countries and identify that changes in low interest rates have a significantly greater impact on bank net interest margins and profitability than changes in high interest rates. They identify that a one percentage point interest rate drop lowers net interest margin by 8 basis points in a high and 20 basis points in a low interest rate environment.

Taken all together, a wide range of authors examine interest rate risks and the impact of interest rate shocks on the banking sector. However, except for Memmel (2008), research with close relation to savings banks interest rate risk is rare. As savings banks have a strong focus on the loan and deposit business and generate earnings mainly via excessive maturity transformation, this paper explains the effects of interest rate shocks on these banks' earnings. In this respect, the papers we identified have limitations. Besides a missing focus on medium-sized savings banks they usually consider only a short 
time period (except Memmel, 2008; Busch \& Memmel, 2015). Furthermore, the developed models do not represent real banks as they primarily focus on only a few business segments of a typical bank - usually the credit and deposit business. Only analyzes of banking supervisory institutions and regulators consider the whole bank's balance sheet and implications on other balance sheet positions caused by interest rate shocks. Moreover, the customer behavior in response to interest changes is barely considered, and the interest rate shocks taken into account are hardly comparable with historical interest rate movements which make them in part unrealistic.

Therefore, the aim of this paper is a new approach of analyzing the impact of interest rate shocks and interest rate risks over several time periods backed by the example of medium-sized savings banks. For this purpose, we developed a comprehensive model which considers all crucial business segments of a bank and also contains the customer behavior in reaction to a rise in interest rates. Moreover, we specifically focus on the development of the banks' capital resources impacted by various more realistic interest rate scenarios, as well as on the variations in the banks' balance sheet positions and the fulfilment of related bank regulatory requirements. Our approach contains a comprehensive and realistic bank model, realistic interest rate scenario simulations and models customers' reactions to interest rate changes. As opposed to existing research this allows more realistic and - especially for practitioners - valuable insights into the interest risks of German savings banks.

\section{Method}

\subsection{Simulated and Analyzed Interest Rate Scenarios}

This article considers ten interest rate scenarios (IRS) that last for 10 time periods each. These IRS are based on time series for the relevant short-, medium- and long-term interest rates in the 1973 to 2015 period in the Euro (EUR) or DEM currency zone, obtained from the time series data base of the German Central Bank shown in Table 1 below.

Table 1. Time series data from German Central Bank for modelling interest rate scenarios

\begin{tabular}{ll}
\hline Interest rate & Used time series of the German Central Bank \\
\hline $\begin{array}{l}\text { Short-term market interest rate } \\
\text { (up to 1 year) }\end{array}$ & $\begin{array}{l}\text { Time series BBK01.SU0343: Money market rates / EURIBOR twelve-month } \\
\text { funds / Monthly average (period covered: January 1999 - December 2015) }\end{array}$ \\
\hline $\begin{array}{l}\text { Medium-term market interest } \\
\text { rate (up to 5 years) }\end{array}$ & $\begin{array}{l}\text { Time series BBK01.WU0901: Yields on debt securities outstanding issued by } \\
\text { residents / Mean residual maturity of more than 4 and up to 5 years / Monthly } \\
\text { average (period covered: January 1999 - December 2015) }\end{array}$ \\
$\begin{array}{ll}\text { Long-term market interest rate } \\
\text { (up to 10 years) }\end{array}$ & $\begin{array}{l}\text { Time series BBK01.WU8608: Yields on debt securities outstanding issued by } \\
\text { residents / Mean residual maturity of more than 9 and up to 10 years / Monthly } \\
\text { average (period covered: January 1999 - December 2015) }\end{array}$
\end{tabular}

IRS1 is a baseline scenario that assumes an unchanged situation of the low interest rates in 2018. IRS2, IRS3 and IRS4 are based on IRS1 and assume interest rate shocks of $+100 \mathrm{bps},+200 \mathrm{bps}$ and $+400 \mathrm{bps}$, respectively. These fictitious one-time parallel shifts in the yield curve are typically used by supervisory institutions or regulators to assess the impact of changed interest rates on the banking industry. However, such interest rate movements did never occur in the Euro (EUR) or DEM currency zone in the 1973 to 2015 period. Therefore, in a next step we contrast these above-mentioned fictitious interest rate scenarios with real historical interest rate movements shown in IRS5 to IRS10 that occurred between 1973 and 2015. This proceeding ensures a high level of realism which makes our findings more valuable for practitioners. The realistic interest rate scenarios IRS5 to IRS10 include rapid and severe shocks, long-lasting interest rates growth with a steepening or even inverse yield curve. In the historical interest rate scenarios IRS5 to IRS10, rising interest rates were simulated for as many periods (equivalent to years) as they lasted. For the remaining periods it is always assumed that the increased interest rate level will last until period $t_{10}$. The same procedure was used to model the interest rate shocks in IRS2 to IRS4.

The scenarios have the following details:

IRS5: Period of rising interest rates that occurred from March 1978 to August 1981. These movements in interest rates lasted approximately five years. A strong inverse yield curve evolved.

IRS6: Rise in interest rates that occurred from April 1988 to August 1992. This resulted again in an inverse yield curve.

IRS7: Interest rate movements from January 1994 to January 1995 that lead to a steepening of the slope of the yield curve and an increase in the level of the interest rates considered.

IRS8: Rise in interest rates that occurred from February 1999 to November 2000. The interest rate level increased by nearly two percentage points, the yield curve flattened. 
IRS9: Boom phase from July 2005 to December 2007. The interest rate level increased by 300 bps over three years. Originally steep, the yield curve gradually flattened out and then turned inverse.

IRS10: Interest rate movements that occurred from October 2010 to July 2011. During this time, a short increase of the interest rate level occurred that leads to a steepening yield curve which then flattened again.

Figure 1 shows the development of the considered short-, medium- and long-term interest rates in the Euro (EUR) or DEM currency zone for the time period 1973 to 2015. The above-mentioned six historical interest rate scenarios IRS6 to IRS10 are shaded in grey.

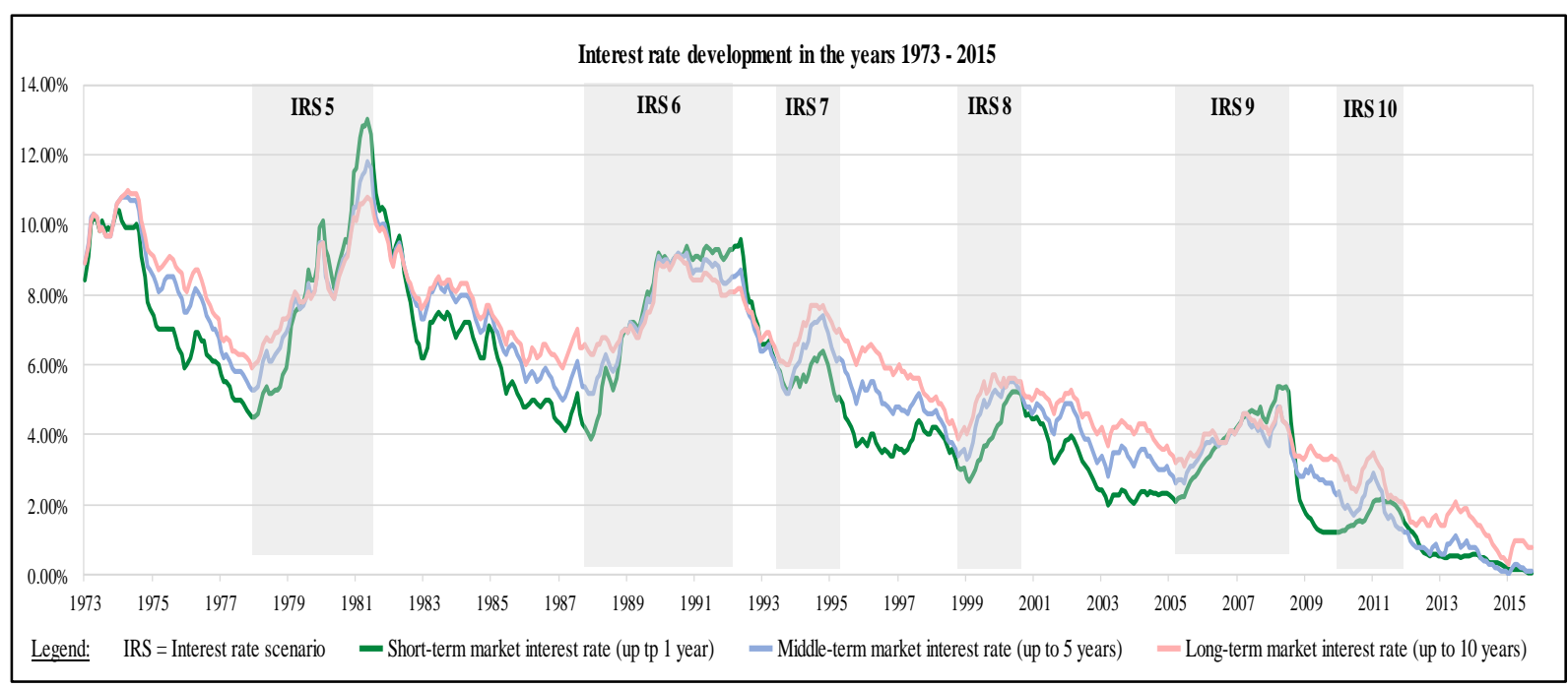

Figure 1. Development of interest rates 1973-2015 (Lichtner 2017, p. 124)

\subsection{Simulation Model for Assessing the Impact of Interest Rate Changes on Banks}

For analyzing the business impact of rising interest rates on banks, it is meaningful to assess how bank balance sheets and its positions may develop in reaction to the interest rate changes. Most commonly researchers determine and assess the impact of interest rate changes by applying it to a given and unchanging balance sheet, but this approach ignores important consequences of interest rate changes.

The assumption of an unchanged balance sheet is not realistic when long-lasting interest rates movements are analyzed because usually customers of banks react interest-elastic to some extent. Therefore, bank balance sheets will usually change when interest rates rise. These changes in the balance sheet have an impact on the bank's revenues and expenses. Moreover, the bank reacts to the changed volume of business with customers by adjusting interbank positions, own security holdings, securitized liabilities and some other items, which entail further changes of revenues and costs. Thus it is indispensable to consider the changes in volume of the most important balance sheet items when assessing the impact of interest rate movements. Therefore, taking into account the impact of interest rate changes on several bank balance sheet positions is a crucial feature of our analyzes which current research usually lacks.

We determined the impact of changing interest rates on bank balance sheet positions by firstly focusing on savings banks to contribute to research. As savings banks are heterogeneous (equivalent business focus, geographical locations and balance sheet totals) we concentrated on medium-sized banks and chose average German savings banks as representatives. In 2015, a total of 413 German savings banks were operating. Our model bank represents an average of this group. The average is calculated of 13 banks which represent the median so that 200 banks have greater and 200 banks have smaller balance sheet totals. The properties of the average of those median banks are shown in Tables 2 and 3 below. Further, all balance sheet positions, especially the equity values, are determined according to the new Basel III requirements. 
Table 2. Initial balance sheet of the considered model bank

Balance sheet structure of the model bank

\begin{tabular}{|c|c|c|c|}
\hline Assets & $\begin{array}{l}\text { Balance sheet } \\
\text { share }\end{array}$ & Liabilities & $\begin{array}{l}\text { Balance sheet } \\
\text { share }\end{array}$ \\
\hline Loans and claims to banks & $12 \%$ & Equity & $8 \%$ \\
\hline Loans and claims to customers & $63 \%$ & Liabilities to banks & $16 \%$ \\
\hline $\begin{array}{l}\text { Debt securities, other fixed income } \\
\text { securities, investments and shares in } \\
\text { affiliated companies }\end{array}$ & $17 \%$ & $\begin{array}{l}\text { Liabilities to customers } \\
\text { (including customer deposits) }\end{array}$ & $73 \%$ \\
\hline $\begin{array}{l}\text { Non-fixed income securities } \\
\text { (own securities deposit) }\end{array}$ & $4 \%$ & Securitized liabilities & $1 \%$ \\
\hline Other & $4 \%$ & Other & $2 \%$ \\
\hline Balance sheet total & $100 \%$ & Balance sheet total & $100 \%$ \\
\hline \multicolumn{2}{|l|}{ Model bank's finance structure } & Variable financing & Fixed financing \\
\hline \multicolumn{2}{|l|}{ Loans and claims to banks } & $6.14 \%$ & $93.86 \%$ \\
\hline \multicolumn{2}{|l|}{ Loans and claims to customers } & $42.72 \%$ & $57.28 \%$ \\
\hline \multicolumn{3}{|c|}{$\begin{array}{l}\text { Debt securities, other fixed income securities, investments and } \\
\text { shares in affiliated companies }\end{array}$} & $100.00 \%$ \\
\hline \multicolumn{3}{|c|}{ Non-fixed income securities (own securities deposit) } & --- \\
\hline \multicolumn{2}{|l|}{ Other } & $50.00 \%$ & $50.00 \%$ \\
\hline \multicolumn{2}{|l|}{ Liabilities to banks } & $5.43 \%$ & $94.57 \%$ \\
\hline \multicolumn{2}{|c|}{ Liabilities to customers (including customer deposits) } & $87.10 \%$ & $12.90 \%$ \\
\hline \multicolumn{2}{|l|}{ Securitized liabilities } & $50.00 \%$ & $50.00 \%$ \\
\hline \multicolumn{2}{|l|}{ Other } & $50.00 \%$ & $50.00 \%$ \\
\hline
\end{tabular}

Table 3. Financing and maturity structure of the model bank's balance sheet positions

\begin{tabular}{lccc}
\hline Model bank's maturity structure & Up to 1 year & Up to 5 years & Up to 10 years \\
\hline Loans and claims to banks & $69.28 \%$ & $19.00 \%$ & $11.72 \%$ \\
\hline Loans and claims to customers & $12.71 \%$ & $29.95 \%$ & $57.34 \%$ \\
\hline $\begin{array}{l}\text { Debt securities, other fixed income securities, investments } \\
\text { and shares in affiliated companies }\end{array}$ & --- & $100.00 \%$ & --- \\
\hline Non-fixed income securities (own securities deposit) & --- & $100.00 \%$ & --- \\
\hline Other & --- & $100.00 \%$ & -- \\
\hline Liabilities to banks & $21.08 \%$ & $43.79 \%$ & $35.13 \%$ \\
\hline Liabilities to customers (including customer deposits) & $94.05 \%$ & $5.04 \%$ & $0.91 \%$ \\
\hline Securitized liabilities & --- & $100.00 \%$ & -- \\
\hline Other & --- & $100.00 \%$ & --
\end{tabular}

In a next step, we focused on determining the statistical correlation between the most crucial balance sheet positions of the developed model bank (see Table 1) due to interest rate changes. Again we used time series data of the German Central Bank and the specific bank balance sheet positions in the years 1999 to 2015 as well as short-, medium- and long-term interest rate data for the years 1973 to 2015 in the Euro (EUR) or DEM currency zone which is shown in Table 4. Then we quantified the statistical correlation between the considered balance sheet positions and the interest rate movements. For balance sheet and income statement positions which proved to be less interest sensitive (such as personnel expenses, 
administrative expenses, net commission earnings, etc.), we use typical ratios based on the real balance sheet and income statement data of the mentioned median savings banks that form our model bank.

Table 4. Time series data from German Central Bank

\section{Variable of the regression Used time series of the German Central Bank equation}

\begin{tabular}{ll}
\hline $\mathrm{M}_{1}$ : Value of the short-term & Time series BBK01.SU0343: Money market rates / EURIBOR twelve- \\
market interest rate (up to 1 & month funds / Monthly average (period covered: January 1999 - December \\
year) & 2015)
\end{tabular}

$\mathrm{M}_{2}$ : Value of the medium-term

Time series BBK01.WU0901: Yields on debt securities outstanding issued market interest rate (up to 5 years)

by residents / Mean residual maturity of more than 4 and up to 5 years / Monthly average (period covered: January 1999 - December 2015)
$\mathrm{M}_{3}$ : Value of the long-term Time series BBK01.WU8608: Yields on debt securities outstanding issued market interest rate (up to 10 years) by residents / Mean residual maturity of more than 9 and up to 10 years / Monthly average (period covered: January 1999 - December 2015)

$\mathrm{B}_{1}$ : Loans and claims to banks

Time series BBK01.SUD124: Effective interest rates of German banks / New business / Loans to non-financial corporations up to EUR 1 million with a floating rate or an initial rate fixation up to 1 year (period covered: January 1999 - December 2015)

$\mathrm{B}_{2}$ : Claims to customers

Time series BBK01.OU0883: Principal assets and liabilities of banks (MFIs) in Germany by category of banks / Lending to non-banks (nonMFIs) / Total / Regional banks and other commercial banks (period covered: January 1999 - December 2015)

$\mathrm{B}_{3}$ : Debt securities and other Time series BBK01.OUZ099: Debt securities and other fixed interest fixed income securities securities / Regional banks and other commercial banks / Multi-office banks (period covered: January 1999 - December 2015)

\begin{tabular}{|c|c|}
\hline $\begin{array}{l}\text { B } 4 \text { : Shares and non-fixed income } \\
\text { securities (own securities } \\
\text { deposit) }\end{array}$ & $\begin{array}{l}\text { Time series BBK01.OUZ100: Shares and other variable yield securities / } \\
\text { Regional banks and other commercial banks / Multi-office banks (period } \\
\text { covered: January } 1999 \text { - December 2015) }\end{array}$ \\
\hline $\begin{array}{l}\mathrm{B}_{5} \text { : Investments and shares in } \\
\text { affiliated companies }\end{array}$ & $\begin{array}{l}\text { Time series BBK01.OUZ101: Participating interests and shares in affiliated } \\
\text { enterprises / Regional banks and other commercial banks / Multi-office } \\
\text { banks (period covered: January } 1999 \text { - December 2015) }\end{array}$ \\
\hline $\mathrm{B}_{6}$ : Liabilities to banks & $\begin{array}{l}\text { Time series BBK01.OUZ106: Liabilities to banks (MFIs) / total / Regional } \\
\text { banks and other commercial banks / Multi-office banks (period covered: } \\
\text { January } 1999 \text { - December 2015) }\end{array}$ \\
\hline $\mathrm{B}_{7}$ : Liabilities to customers & $\begin{array}{l}\text { Time series BBK01.OUZ107: Liabilities to non-banks (non-MFIs) / total / } \\
\text { Regional banks and other commercial banks / Multi-office banks (period } \\
\text { covered: January } 1999 \text { - December 2015) }\end{array}$ \\
\hline $\mathrm{B}_{8}$ : Securitized liabilities & $\begin{array}{l}\text { Time series BBK01.OUZ108: Securitized debts / total / Regional banks and } \\
\text { other commercial banks / Multi-office banks (period covered: January } 1999 \\
\text { - December 2015) }\end{array}$ \\
\hline $\begin{array}{l}\text { B }_{9} \text { : Subordinated liabilities and } \\
\text { profit participation capital }\end{array}$ & $\begin{array}{l}\text { Time series BBK01.OUZ110: Subordinated liabilities / Regional banks and } \\
\text { other commercial banks / Multi office banks (period covered: January } 1999 \\
\text { - December 2015) }\end{array}$ \\
\hline
\end{tabular}

The statistical correlation between the balance sheet and income statement positions due to interest rate changes is quantified by means of "Partial Least Squares Regression" (PLS Regression) which is a distribution-free method and a preferred approach for value forecasts based on correlated predicted variables, which usually provides more precise forecasts than alternative methods (Schendera, 2014, p. 351/355). Thus, PLS regressions are a very efficient prediction tool that can be applied to a diverse set of data, especially with correlated variables, or a broad range of questions where common regression models cannot be used. (Boulesteix, Strimmer, \& Korbinian, 2006, p. 41). Many authors prove that in such cases PLS regressions yield better predictions, e. g. Laitinen (2006) who demonstrates its efficiency in payment 
default prediction, or Yeniay and Göktas (2002) who showed theoretically and with a comprehensive data set that PLS regressions yield better predictions than other methods. $\mathrm{Wu}(2014$, p. 754$)$ also recommends PLS regressions for problems due to correlated data that cannot be solved with common regression methods. We choose PLS regressions for predicting values as we require reliable predictions; however our data has strongly correlated predicted variables (short-, medium-, long-term interest rates) as shown in Table 5 below. As a result, our data set is exposed to multicollinearity. Alternative methods like the Principal Component Analysis usually perform worse, and the Ridge-Regression has the downside that the k-values are determined subjectively which may lead to poor estimation functions (Maddala, 1977, p. 192).

Table 5. Pearson's correlation matrix for assessing the multicollinearity within the data set

\begin{tabular}{c|c|c|c}
\hline \multirow{2}{*}{$\begin{array}{c}\text { Predicted variables } \mathbf{M}_{\mathbf{i}} \\
\text { of the regression equations }\end{array}$} & \multicolumn{3}{|c}{ Pearson's correlation matrix } \\
\cline { 2 - 4 } & $\begin{array}{c}\text { (The correlations are significant at a level of 0,05 / 2-sided). } \\
\text { short-term market } \\
\text { interest rate } \\
\text { (up to 1 year) }\end{array}$ & $\begin{array}{c}\text { medium-term } \\
\text { market interest rate } \\
\text { (up to 5 years) }\end{array}$ & $\begin{array}{c}\text { long-term market } \\
\text { interest rate } \\
\text { (up to 10 years) }\end{array}$ \\
\hline $\begin{array}{c}\mathrm{M}_{1}: \text { Value of the short-term market } \\
\text { interest rate (up to 1 year) }\end{array}$ & 1,000 & 0,928 & 0,875 \\
\hline $\mathrm{M}_{2}:$ Value of the medium-term market \\
interest rate (up to 5 years)
\end{tabular}

Furthermore, the values predicted with our PLS regressions are corrected with a correcting-algorithm (expressed by the term $\mathrm{S}_{\mathrm{G}} \cdot \mathrm{Z}$ in Table 6) based on 1000 Monte Carlo simulations and by using the specific standard error of each regression equation as a balancing variable. This helps to eliminate prediction inaccuracies caused by the multicollinearity in our data (see Table 5) and to achieve reliable regression equations. Table 2 presents the results of the PLS regressions in the form of regression equations. In detail we quantified the interest rate dependencies of 9 balance sheet positions (see equations [1] to [9] in Table 6) in relation to the movement of the short-term, medium-term and long-term interest rates.

The regression equations shown in Table 6 reveal the following properties:

- Non-bank deposits and non-bank liabilities react negatively and are interest-elastic to changes in market interest rates. The medium-term rate is the relevant market rate. An increase in medium-term interest rate triggers a decrease in deposit and loan volumes. Non-bank deposits react slightly more than loans to non-banks. Depositors seem to increasingly switch to alternatives such as securities when interest rates rise (see Table 6, regression equations [2] and [7]).

- In contrast, interbank loans and the bank's bond issues show positive interest elasticity (see regression equations [6] and [8]). It seems that interbank loans and bond issues are needed by the bank to compensate for the decrease of the customer deposits.

- Besides that, banks are increasingly investing in their own securities deposit when interest rates rise to compensate for the decline in the lending business (see regression equation [4]).

- Furthermore, on the assets side "debt securities and other fixed income securities" show strong negative interest elasticity (see regression equation [3]).

- Interbank deposits react positively to short-term money market rates, but negatively to long-term interest rates (see regression equation [1]).

- Investments on the assets side and subordinated liabilities on the liability side do not seem to be very interestsensitive (see regression equations [5] and [9]). 
Table 6. Regression equations for the balance sheet positions of the considered model bank in dependence of interest rate movements

\section{Regression equations of the PLS Regressions}

\begin{tabular}{|c|c|c|c|c|c|c|c|c|c|}
\hline Results of the PLS Regressions ${ }^{1)}$ & [1] & [2] & [3] & [4] & [5] & [6] & [7] & [8] & [9] \\
\hline Coefficient of Determination $\mathrm{R}^{2}$ & 0.492 & 0.731 & 0.428 & 0.741 & 0.278 & 0.553 & 0.819 & 0.523 & 0.333 \\
\hline Standard error of the estimation $\sigma_{\mathrm{B}}$ & 19.147 & 46.296 & 14.951 & 3.962 & 1.578 & 20.181 & 49.370 & 9.646 & 1.294 \\
\hline Average value $\overline{B_{1}}$ of the database $B_{i}$ & 172.99 & 422.47 & 119.45 & 16.38 & 8.32 & 169.43 & 406.04 & 49.77 & 7.53 \\
\hline Relation of the $\sigma_{B}$ to $B_{i}$ & $11.07 \%$ & $10.96 \%$ & $12.52 \% 2$ & $24.19 \% 1$ & $18.98 \% 1$ & $11.91 \% 1$ & $12.16 \% 1$ & $9.38 \% 1$ & $17.20 \%$ \\
\hline $\begin{array}{l}\text { Share of variable } B_{i} \text { on balance sheet } \\
\text { total at } t_{0}\end{array}$ & $12.47 \%$ & $62.63 \%$ & $16.69 \%$ & $4.18 \%$ & 0.93 & $15.85^{\circ}$ & $73.41 \%$ & $0.72 \%$ & $0.41 \%$ \\
\hline
\end{tabular}

Specification of the regression equations:

$\begin{array}{ll}{[1] \mathrm{B}_{1, \mathrm{i}}=213.53+1681.21 \cdot \mathrm{M}_{1, \mathrm{i}}-1398.81 \cdot \mathrm{M}_{2, \mathrm{i}}-1212.01 \cdot \mathrm{M}_{3, \mathrm{i}}+\mathrm{S}_{\mathrm{G}} \cdot \mathrm{Z}} & ; \text { with } \mathrm{i}=1, \ldots, 204 \\ {[2] \mathrm{B}_{2, \mathrm{i}}=585.18+1443.07 \cdot \mathrm{M}_{1, \mathrm{i}}-4092.84 \cdot \mathrm{M}_{2, \mathrm{i}}-2308.37 \cdot \mathrm{M}_{3, \mathrm{i}}+\mathrm{S}_{\mathrm{G}} \cdot \mathrm{Z}} & ; \text { with } \mathrm{i}=1, \ldots, 204 \\ {[3] \mathrm{B}_{3, \mathrm{i}}=128.74-427.10 \cdot \mathrm{M}_{1, \mathrm{i}}-1659.78 \cdot \mathrm{M}_{2, \mathrm{i}}+1440.03 \cdot \mathrm{M}_{3, \mathrm{i}}+\mathrm{S}_{\mathrm{G}} \cdot \mathrm{Z}} & ; \text { with } \mathrm{i}=1, \ldots, 204 \\ {[4] \mathrm{B}_{4, \mathrm{i}}=6.48+37.69 \cdot \mathrm{M}_{1, \mathrm{i}}+653.99 \cdot \mathrm{M}_{2, \mathrm{i}}-292.23 \cdot \mathrm{M}_{3, \mathrm{i}}+\mathrm{S}_{\mathrm{G}} \cdot \mathrm{Z}} & ; \text { with } \mathrm{i}=1, \ldots, 204 \\ {[5] \mathrm{B}_{5, \mathrm{i}}=7.38-17.69 \cdot \mathrm{M}_{1, \mathrm{i}}+171.69 \cdot \mathrm{M}_{2, \mathrm{i}}-104.92 \cdot \mathrm{M}_{3, \mathrm{i}}+\mathrm{S}_{\mathrm{G}} \cdot \mathrm{Z}} & ; \text { with } \mathrm{i}=1, \ldots, 204 \\ {[6] \mathrm{B}_{6, \mathrm{i}}=104.38-163.79 \cdot \mathrm{M}_{1, \mathrm{i}}-1109.31 \cdot \mathrm{M}_{2, \mathrm{i}}+2940.40 \cdot \mathrm{M}_{3, \mathrm{i}}+\mathrm{S}_{\mathrm{G}} \cdot \mathrm{Z}} & ; \text { with } \mathrm{i}=1, \ldots, 204 \\ {[7] \mathrm{B}_{7, \mathrm{i}}=619.49+2841.49 \cdot \mathrm{M}_{1, \mathrm{i}}-7512.03 \cdot \mathrm{M}_{2, \mathrm{i}}-1906.83 \cdot \mathrm{M}_{3, \mathrm{i}}+\mathrm{S}_{\mathrm{G}} \cdot \mathrm{Z}} & \text {; with } \mathrm{i}=1, \ldots, 204 \\ {[8] \mathrm{B}_{8, \mathrm{i}}=33.41+446.77 \cdot \mathrm{M}_{1, \mathrm{i}}+337.58 \cdot \mathrm{M}_{2, \mathrm{i}}-133.81 \cdot \mathrm{M}_{3, \mathrm{i}}+\mathrm{S}_{\mathrm{G}} \cdot \mathrm{Z}} & ; \text { with } \mathrm{i}=1, \ldots, 204 \\ {[9] \mathrm{B}_{9, \mathrm{i}}=5.30-55.44 \cdot \mathrm{M}_{1, \mathrm{i}}+31.96 \cdot \mathrm{M}_{2, \mathrm{i}}+77.75 \cdot \mathrm{M}_{3, \mathrm{i}}+\mathrm{S}_{\mathrm{G}} \cdot \mathrm{Z}} & ; \text { with } \mathrm{i}=1, \ldots, 204\end{array}$

with the following variables $\mathrm{M}_{\mathrm{i}}$ of the market interest rate level:

$\mathrm{M}_{1, \mathrm{i}}=$ Value of the short-term market interest rate (up to 1 year) for observation i

$\mathrm{M}_{2, \mathrm{i}}=$ Value of the medium-term market interest rate (up to 5 years) for observation $\mathrm{i}$

$\mathrm{M}_{3, \mathrm{i}}=$ Value of the long-term market interest rate (up to 10 years) for observation $\mathrm{i}$

the variables $\mathrm{B}_{\mathrm{i}}$ of business development:

$\mathrm{B}_{1, \mathrm{i}}=$ Value of loans and claims to banks for observation $\mathrm{i}$

$\mathrm{B}_{2, \mathrm{i}}=$ Value of the claims to customers for observation $\mathrm{i}$

$\mathrm{B}_{3, \mathrm{i}}=$ Value of debt securities and other fixed income securities for observation $\mathrm{i}$

$\mathrm{B}_{4, \mathrm{i}}=$ Value of shares and non-fixed income securities (own securities deposit) for observation $\mathrm{i}$

$\mathrm{B}_{5, \mathrm{i}}=$ Value of investments and shares in affiliated companies for observation $\mathrm{i}$

$\mathrm{B}_{6, \mathrm{i}}=$ Value of liabilities to banks for observation $\mathrm{i}$

$\mathrm{B}_{7, \mathrm{i}}=$ Value of liabilities to customers for observation $\mathrm{i}$

$\mathrm{B}_{8, \mathrm{i}}=$ Value of securitized liabilities for observation $\mathrm{i}$

$\mathrm{B}_{9, \mathrm{i}}=$ Value of subordinated liabilities and profit participation capital for observation $\mathrm{i}$

and the parameters for adjusting the estimation error within the regression model:

$S_{B}=$ Range of the standard error in the estimation of $B_{k, i}$ with $-\sigma_{B} \leq S_{B} \leq+\sigma_{B}$

$\sigma_{\mathrm{B}}=$ Standard error in the estimation of $\mathrm{B}_{\mathrm{k}, \mathrm{i}}$

$\mathrm{Z}=$ Random number with the value range $0 \leq \mathrm{Z} \leq 1$

Moreover, according to Table 6 not all regression equations have high coefficients of determination $\left(\mathrm{R}^{2}\right)$. So, regression equations $1\left(\mathrm{R}^{2}=0.492\right), 3\left(\mathrm{R}^{2}=0.428\right), 5\left(\mathrm{R}^{2}=0.278\right)$ and $6\left(\mathrm{R}^{2}=0.333\right)$ contain an $\mathrm{R}^{2}$ of less than 0.50 . However, these regression equations show only a standard error of the estimation that is less than $20 \%$, when comparing it to the 
specific average value $\bar{B}_{1}$ of the underlying database $B_{\mathrm{i}}$. The only exception here is regression model 4 with a value of $24.19 \%$ but this is less critical as the share of the variable $\mathrm{B}_{4}$ on the model bank's balance sheet total at $\mathrm{t}_{0}$ is only $4.18 \%$. As the claim of this paper is to have a realistic, comprehensive model bank which considers all crucial business segments, we therefore included these regression equations.

The varying values of the elements within the regression equations, e. g. the value of 585.18 in regression equation 2 and the value of 619.49 in regression equation 7, are traced back to their time series (see Table 4) and the balance sheet shares of these businesses (see also Table 2). Regression equation 2 represents the loans (claims to customers with a balance share of $63 \%$ at $t_{0}$ ) and regression equation 7 the liabilities to customers (balance share in $t_{0}=73 \%$ ). This is the core business of the model bank as well as of German savings banks, the underlying time series and business volumes contain higher values compared to the other variables $B_{i}$ of business development. Also, this issue leads to varying values of the standard errors in the regression equations. As a result, regression equations 2 and 7 have high values while regression equation 9 only has a low one (see also Table 6).

Overall it turns out that crucial bank balance sheet positions such as customer deposits, loans to customers, interbank loans and own securities deposit investments are significantly interest-elastic. For example, if interest rates increase by 1 percentage point due to an interest rate shock (100 bps parallel upward shift of the yield curve), customer loans and customer deposits decrease c. p. by around $5 \%$, while the bank's own securities deposit increases by $6 \%$. Securitized liabilities double, however from a very low level.

There is a difference in interest elasticity regarding short-, medium- and long-term market interest rates. In detail customer deposits and loans react negatively to medium- and long-term interest rates and positively to short-term interest rates. If only short-term interest rates rise by 200 bps while other interest rates remain unchanged, customer deposits will increase by $4 \%$ and customer loans by $3 \%$. Interbank loans decline slightly by $1 \%$, while interbank assets, from a low level, increase by $16 \%$.

On the other hand, if medium- and long-term interest rates rise (presumably by $200 \mathrm{bps)}$ while the short-term interest rate remains constant - this is the scenario that some market participants expect for the future - then customer related business will be reduced on the assets and liabilities side by $12 \%$ to $15 \%$. Refinancing through securitized liabilities and interbank loans will increase. On the asset side, the bank's own securities deposit will increase by $10 \%$, while interbank deposits decline by one quarter. The balance sheet total will shrink slightly.

In conclusion our regression equations prove that bank balance sheet positions are elastic to interest rate changes. Therefore do interest changes not only cause direct effects on bank's earnings, but also indirect effects via changes of the interest-elastic bank balance sheet positions. The latter should not be ignored when analyzing the impact of changing market interest rates onto banks.

\subsection{Identified Types of Bank's Earnings Effects due to Interest Rate Changes}

Considering the balance sheet effects described above and their consequences, three bank's earnings effects can be distinguished that are triggered by changes in interest rates:

(i) Direct earnings effects

(ii) Indirect earnings effects

(iii) Induced earnings effects

The direct earnings effects are the earnings effects of changed market interest rates with unchanged balance sheet positions. Only these direct effects are captured by simple models for assessing interest rate shocks, which certainly do not reflect all effects on a bank's earnings situation.

Indirect earnings effects result from customer reactions to the interest rate changes. As a consequence, customer related balance sheet positions increase or decrease with medium- and long-term consequences for a bank's earnings. The reaction of customer related positions is caused by the positive or negative interest elasticity of the customers.

Induced earnings effects are triggered by counter-reactions of banks by which they intend to compensate changes in the business volumes with customers. These effects are so to say "induced" by customer reactions due to changes in the market interest rates.

The following example will illustrate these different earnings effects. (We present the related exact calculations in the next chapter). Typically, a bank performs maturity transformation and refinances long-term assets through short-term liabilities. The typical (direct) effect of a one-time interest rate shock is that the liability side of a bank balance sheet becomes more expensive while earnings from lendings on the asset side initially remain unchanged $(\rightarrow$ direct earnings effect). In a next step the customers react to the interest rate change according to their interest elasticity. This leads to decreased deposit volumes due to reallocations of customer-related balance sheet positions. As a result, exactly the 
problematic balance sheet position is being reduced and interest expenses decline slightly $(\rightarrow$ indirect earnings effect). This reaction tends to dampen the earning risks of interest rate increases. Simultaneously, the credit volume declines and releases funds. The bank reinvests these released funds into its own securities deposit at the new, higher interest rates ( $\rightarrow$ induced earnings effect) or these funds are used to refinance the occurring deposit deduction. Overall, rises in interest rates result in a replacement of loans with securities and a decrease of deposits. Consequently, the balance sheet total diminishes which reduces the volume of maturity transformation and helps the bank to handle the rise in interest rates.

Due to the outlined negative interest elasticity of non-banks, even a sharp rise in interest rates may be more favorable than a lower increase because the latter leads to a stronger reaction from depositors and accelerates the reduction of the maturity transformation. Further, it remains unclear how strongly the reallocation of customer related positions effects the bank's commission revenues.

In conclusion, when analyzing persistent movements of interest rate increases, clear distinction between direct, indirect and induced effects on bank's earnings is crucial. Interest rate changes initially cause an adjustment of the profits and costs of all short-term bank balance sheet positions with unchanged business volumes ( $\rightarrow$ direct earnings effects). Moreover, there are not only earning effects, but also volume effects in the bank balance sheets that impact also the costs, as customers react interest-elastically to the changed interest rates with reallocations which trigger changes in bank balance sheets and leads to indirect effects on bank's earnings ( $\rightarrow$ indirect earnings effects). As a result of the customer behavior due to interest rate movements, banks respond with counter-reactions such as interbank operations to compensate the changes in the customer related business volume, which in turn results in further effects on the earnings situation $(\rightarrow$ induced earnings effects).

\section{Results}

The results of the ten simulated interest rate scenarios described in the previous Section III.1 which were applied to the considered model bank are illustrated below in Figure 2. The dashed line indicates the development of the annual surplus of the considered model bank. The initial situation is period $t_{0}$. The development of the market interest rates is shown with blue, green and red lines. For the starting point $t_{0}$, the interest rates correspond to the average interest rates in 2015 for the Euro (EUR) currency zone which were calculated based on time series of the German Central Bank for the relevant market rates for the months January to December 2015. The occurring interest rate changes after the starting point $t_{0}$, reflect the respective interest rate scenarios. 


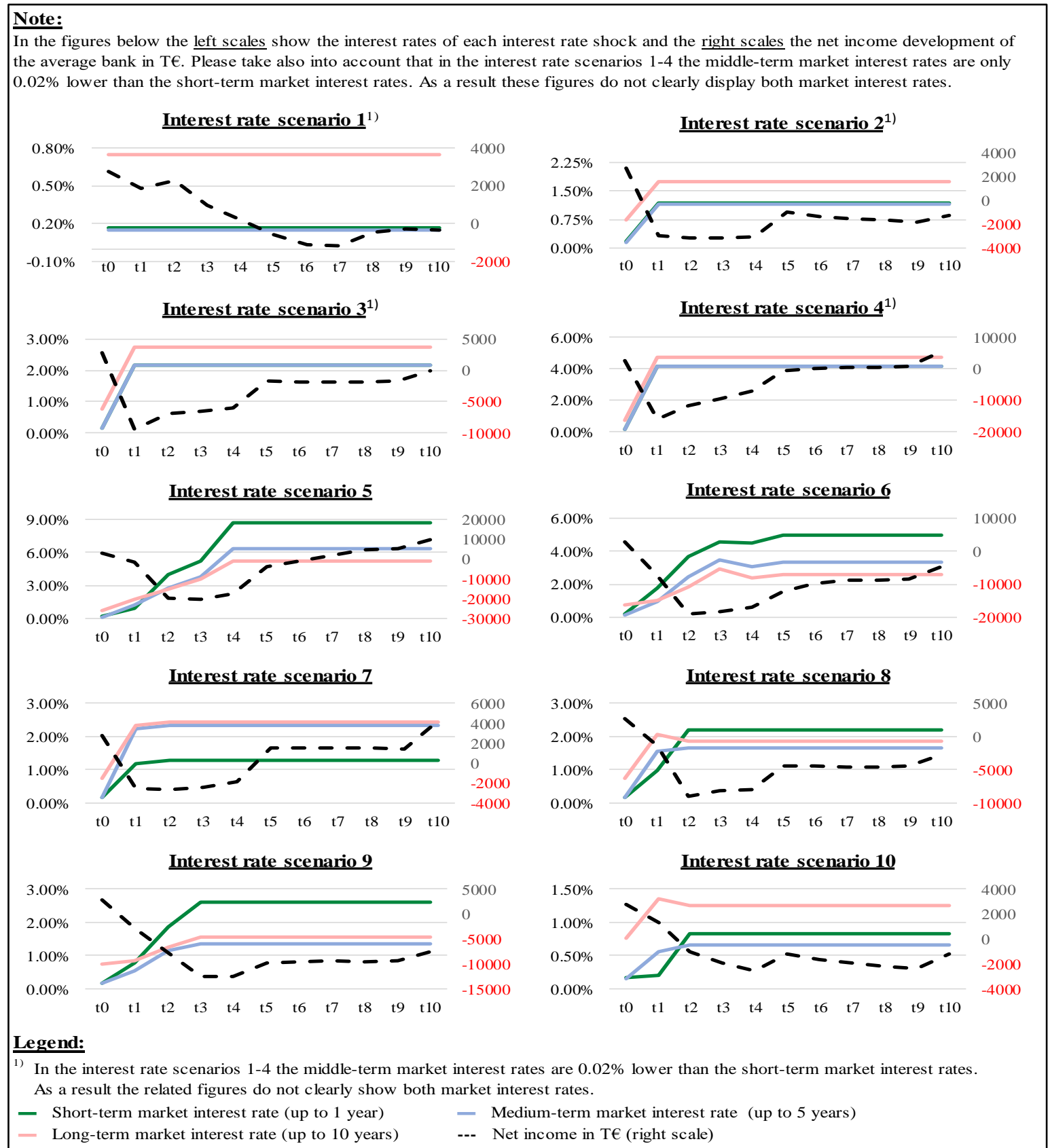

Figure 2. Simulated interest rate scenarios and their effects on the net income of the model bank 
Table 7 presents the impact on the profit and loss of the model bank caused by the simulated interest rate scenarios (IRS1 to IRS10) for each of the ten time periods considered. The depiction shows how the model bank's equity increases or decreases relative to the initial value in $\mathrm{t}_{0}$ (see also Figure 2). More details about the simulated interest rate scenarios are available in Section III.1.

Table 7. Profit and loss effects of the simulated interest rate scenarios for the model bank in per cent

\begin{tabular}{|c|c|c|c|c|c|c|c|c|c|c|c|}
\hline \multirow{2}{*}{$\begin{array}{l}\text { Interest } \\
\text { rate } \\
\text { scenario }\end{array}$} & \multicolumn{10}{|c|}{ Impact on the model bank's profit/loss for each time period } & \multirow{2}{*}{$\begin{array}{c}\text { Cumulated } \\
\text { effect }\end{array}$} \\
\hline & $\mathbf{t}_{\mathbf{1}}$ & $\mathbf{t}_{2}$ & $\mathbf{t}_{3}$ & $\mathbf{t}_{4}$ & $\mathbf{t}_{5}$ & $\mathbf{t}_{6}$ & $\mathbf{t}_{7}$ & $\mathbf{t}_{\mathbf{8}}$ & t9 & $\mathbf{t}_{10}$ & \\
\hline IRS1 & $+1.4 \%$ & $+1.7 \%$ & $+0.7 \%$ & $0.1 \%$ & $-0.4 \%$ & $-0.8 \%$ & $-0.8 \%$ & $-0.3 \%$ & $-0.2 \%$ & $-0.3 \%$ & $+1.1 \%$ \\
\hline IRS2 & $-2.2 \%$ & $-2.3 \%$ & $-2.3 \%$ & $-2.2 \%$ & $-0.7 \%$ & $-1.0 \%$ & $-1.1 \%$ & $-1.2 \%$ & $-1.3 \%$ & $-0.9 \%$ & $-15.2 \%$ \\
\hline IRS3 & $-6.8 \%$ & $-5.0 \%$ & $-4.7 \%$ & $-4.4 \%$ & $-1.3 \%$ & $-1.4 \%$ & $-1.3 \%$ & $-1.4 \%$ & $-1.3 \%$ & $\pm 0.0 \%$ & $-27.6 \%$ \\
\hline IRS4 & $-11.6 \%$ & $-8.4 \%$ & $-7.0 \%$ & $-5.2 \%$ & $-0.4 \%$ & $+0.2 \%$ & $+0.3 \%$ & $+0.5 \%$ & $+0.7 \%$ & $+3.9 \%$ & $-27.0 \%$ \\
\hline IRS5 & $-1.0 \%$ & $-14.5 \%$ & $-14.9 \%$ & $-12.9 \%$ & $-3.0 \%$ & $-0.7 \%$ & $+1.5 \%$ & $+3.6 \%$ & $+3.8 \%$ & $+7.2 \%$ & $-30.9 \%$ \\
\hline IRS6 & $-5.5 \%$ & $-13.8 \%$ & $-13.3 \%$ & $-12.5 \%$ & $-8.9 \%$ & $-7.1 \%$ & $-6.5 \%$ & $-6.5 \%$ & $-6.2 \%$ & $-3.5 \%$ & $-83.8 \%$ \\
\hline IRS7 & $-1.8 \%$ & $-2.0 \%$ & $-1.8 \%$ & $-1.4 \%$ & $+1.1 \%$ & $+1.1 \%$ & $+1.1 \%$ & $+1.1 \%$ & $+1.0 \%$ & $+3.1 \%$ & $+1.5 \%$ \\
\hline IRS8 & $-1.1 \%$ & $-6.6 \%$ & $-6.0 \%$ & $-5.9 \%$ & $-3.2 \%$ & $-3.3 \%$ & $-3.4 \%$ & $-3.3 \%$ & $-3.3 \%$ & $-2.1 \%$ & $-38.2 \%$ \\
\hline IRS9 & $-2.1 \%$ & $-5.7 \%$ & $-9.2 \%$ & $-9.2 \%$ & $-7.2 \%$ & $-7.0 \%$ & $-6.9 \%$ & $-7.0 \%$ & $-6.9 \%$ & $-5.6 \%$ & $-66.8 \%$ \\
\hline IRS10 & $+0.9 \%$ & $-0.8 \%$ & $-1.4 \%$ & $-1.9 \%$ & $-0.9 \%$ & $-1.3 \%$ & $-1.4 \%$ & $-1.6 \%$ & $-1.7 \%$ & $-0.9 \%$ & $-11.0 \%$ \\
\hline
\end{tabular}

Next we briefly discuss the effects of the simulated interest rate scenarios for the model bank's profit and loss shown in Table 7:

\section{Scenario IRS 1: Unchanged market interest rates}

The interest rate scenario IRS1 which assumes unchanged interest rates represents the current market situation with a low level of interest rates, results in a slow decline of the bank's net income. The reason for this is that former high-yield lending operations expire and have to be replaced by new loans at lower interest rates. The remaining margin earned with the lower interest rates is not high enough to generate sufficient annual surplus. A reduction in operating cost and an increase in revenues, for example in the commission section, are strongly needed. These are exactly the measures that banks are intensively working on today.

\section{Scenarios IRS2 to 4: One-time interest shocks}

The interest rate scenarios IRS2 to IRS4 which assume one-time interest rate shocks and parallel shifts of +100 bps, +200 bps and +400 bps in the entire yield curve show high losses in the first time periods the origin of which lies in the maturity transformation of the average savings bank. As the maturity transformation effect phases out, the earnings situation gradually normalizes.

In the scenario IRS4 with a very high interest rate shock of $+400 \mathrm{bps}$, Figure 2 clearly illustrates the consequences of the interest-elastic behavior of bank customers. Both depositors and borrowers are interest sensitive which leads to a declined volume of loans and deposits. This reduces the problems caused by the maturity transformation of the model bank in the starting point $\mathrm{t}_{0}$. Growing securities income stabilizes the earnings situation so that the +400 bps interest rate shock has no greater negative impact than the $+200 \mathrm{bps}$ interest rate shock.

\section{Scenario IRS5, 6, 8 and 9: Slow and long-lasting interest rate increases}

During the interest rate scenarios IRS5, IRS6, IRS8 and IRS9, in which the rise in market rates lasts over several time periods, the model bank initially gains time for reacting. This way the bank is not confronted with a shock but with a gradual increase of the market rates. The annual surplus only gradually worsens due to maturity transformation; this allows the bank to react. Of course, a requirement for good decisions would be now the ability of the bank to correctly predict the further interest rate development.

If the bank has no strong prediction power or ability to forecast, it cannot draw an advantage from the time gained. Likely, when interest rates move only slightly customers do not react substantially and balance sheet remains more or less unchanged. For the bank the problems from maturity transformation still remain. As a result, earnings do not significantly recover over time and remain permanently negative.

To sum up, these scenarios represent the most dangerous ones for banks, especially IRS6 and IRS9. The reasons are that IRS5, IRS6, IRS8 and IRS9 are historical scenarios which over time lead to inverse yield curves. If this yield curve structure persists over long periods of time it will cause a massive burden for a medium-sized savings bank that conducts maturity transformation.

Another effect stems from the comparatively low increase of the market interest rates. Our simulations show that in this case 
the customer reactions are small too. Deposits are not reduced, and banks must finance expensive deposits for a longer period of time. Furthermore, lending operations generate higher returns only very slowly due to the maturity transformation. As a consequence, banks that do not react actively and that have unprecise interest face substantial losses.

Therefore the bank needs to act quickly to keep deposit rates below the relevant market interest rates to reduce costs and fend off new deposits. However it is unclear whether this can be done in a transparent market with international competitors and without generating liquidity shortages.

Compared to German savings banks, international banks have a lower volume of fixed-rate long-term loans and therefore do not have to react here because they immediately generate higher revenues when market rates rise. These revenues let international banks offer higher rates on their deposits quickly. This increases competitive pressure on other retail banks that typically conduct significant maturity transformation, or to a liquidity outflow as it was the case in the American Savings \& Loans Crisis.

\section{Scenarios IRS7 and 10: Fast interest rate increase with a steepening yield curve}

The interest rate scenarios IRS7 and IRS10 show slightly better results for the model bank's earnings than IRS6 and IRS9 (Figure 2, Table 7). The reason for this is that these scenarios lead to relatively steep yield curve which has advantages for banks with a positive maturity transformation. In this case the model bank generates sufficient margins with new business after the initial maturity transformation effects have expired (Table 7, sixth column " $\mathrm{t}_{5}$ "). This effect is particularly relevant in scenario IRS7 where medium- and long-term market interest rates rise more strongly than shortterm rates and are above those.

\section{Conclusion}

We observed that an increase in market interest rates generally leads to a falling net income of medium-sized savings banks. One-time interest shocks and therefore the scenarios IRS2 to IRS4 typically imply a lower decline of earnings than some of the historical interest scenarios - particularly the scenarios IRS6 and IRS9.

Furthermore, we showed that one-time interest rate shocks, mostly used by banking supervisors, regulators or banks to assess interest rate risks, are partly misleading as they reveal only the massive declines in net income during the first time period(s) after the shock, but do not reflect their long-term impact. This becomes evident especially when interest rates change gradually. This may even lead to an inverse yield curve with severe downsides for bank income. Furthermore, these models and assessments do not consider effects on the bank that stem from customer reactions due to interest rate changes.

Our methodological approach used business data from real banks as well as real interest rate scenarios to analyze the interest rate risk of medium-sized savings banks. Furthermore, we included the customer reactions due to changed market rates as they occurred in the past, based on the historical interest elasticity of the bank's customers. Thus our findings especially for the historical interest rate scenarios - are closer to reality than simple interest shock investigations conducted in the past (see for example financial stability reports of the German Central Bank mentioned in Section II). We achieved this realistic insight with the help of a comprehensive and realistic bank model, realistic interest rate scenarios and by considering customer's reactions due to interest rate changes. Therefore, our findings are backed by several papers (Memmel, 2008; Deutsche Bundesbank, 2006; Deutsche Bundesbank, 2014; IMF, 2011; Bundesministerium der Finanzen, 2014).

In none of our simulations a model bank lost all of its equity. On the other side our simulations show that in most cases not all banking regulatory ratios, especially the regulatory capital requirements, could be met. Also, the regulatory liquidity ratios are difficult to comply with. As a consequence, periods of increased interest rates are stress periods for the relationship between banks, banking supervisors and regulators.

Altogether, we consider customer reactions due to interest changes that stem from customer's interest elasticity to be of significant importance. These customer reactions lead to a restructuring of bank balance sheets. Customer loans decrease when market rates rise. The same applies to customer deposits. As a consequence, interbank positions are affected and the bank's security holdings react strongly. To a small extent the latter one helps banks with a positive maturity transformation because it enables them to quicker adjust their balance sheet to the new interest level. The long-term income development is consequently less severely affected and gives the banks time for raising equity to improve liquidity.

Based on our findings, we recommend that banks and regulators include historical interest rate movements in their analyses as one-time parallel upshifts of the yield curve are not appropriate for determining the impact of related interest rate risks on banks' balance sheets, earnings or regulatory requirements. We also suggest a stronger control of the financing and maturity structure of German savings banks to avoid maturity mismatch on long-term fixed rate loans. Moreover, we think that central banks should promote the standardization of interest rate spreads to ensure that bank managers raise appropriate risk premiums for compensating high risks because of maturity mismatch on long-term fixed rate loans. Also, 
the bank management should pay more attention to the BCBS risk management framework in the Basel II and Basel III regulations, the related supervisory guidelines and risk management principles (see e.g. BCBS, 2000; BCBS, 2006; BCBS, 2009; BCBS, 2011; BCBS, 2016). Applying these guidelines facilitates the controlling of losses and ensures appropriate capital adequacy ratios to better cushion abrupt changes in the interest rates.

\section{References}

Alessandri, P., \& Nelson, B. D. (2014). Simple banking: profitability and the yield curve. Banca d'Italia working paper No. 945 . https://doi.org/10.2139/ssrn.2413438

BCBS (2000). Basel Committee on Banking Supervision: Principles for the Management of Credit Risk. Bank for International Settlements, July 2000, Basel, Switzerland.

BCBS (2006). Basel Committee on Banking Supervision: Sound credit risk assessment and valuation for loans. Bank for International Settlements, July 2006, Basel, Switzerland.

BCBS (2009). Basel Committee on Banking Supervision: Enhancements to the Basel II framework. Bank for International Settlements, July 2009, Basel, Switzerland.

BCBS (2011). Basel Committee on Banking Supervision: Principles for the Sound Management of Operational Risk. Bank for International Settlements, July 2011, Basel, Switzerland.

BCBS (2016). Basel Committee on Banking Supervision: Standards - Interest rate risk in the banking book. Bank for International Settlements, April 2016, Basel, Switzerland.

Borio, C., Gambacorta, L., \& Hofmann, B. (2017). The influence of monetary policy on bank profitability. International Finance, 20, 48-63. https://doi.org/10.1111/infi.12104

Boulesteix, A. L., \& Strimmer, K. (2006). Partial least squares: a versatile tool for the analysis of high-dimensional genomic data, Briefings in Bioinformatics, 8(1), 32-44. https://doi.org/10.1093/bib/bbl016

Bundesministerium der Finanzen, Ed. (2014): Ausschuss für Finanzstabilität - Erster Bericht an den Deutschen Bundestag. Berlin, Germany.

Busch, R., \& Memmel, C. (2015). Banks ' net interest margin and the level of interest rates. Deutsche Bundesbank Discussion Paper, No. 16/2015.

Campbell, J. Y., Lo, A. W., \& MacKinlay, A. C. (1997). The Econometrics of Financial Markets. 2. Edition, Princeton University Press, New Jersey.

Chaudron, R. (2018). Bank's interest rate risk and profitability in a prolonged environment of low interest rates. Journal of Banking and Finance, 89, 94-104.

Chen, R. R. (1996). Understanding and Managing Interest Rate Risks. River Edge, NJ: World Scientific Publishing. https://doi.org/10.1142/3182

Claessens, S., Coleman, N., \& Donnelly, M. (2017). Low-For-Long interest rates and banks' interest margins and profitability: Cross-country evidence. International Finance Discussion Papers, Number 1197, February 2017. https://doi.org/10.17016/IFDP.2017.1197

Cornyn, A. G., Klein, R. A., \& Lederman, J. (2000). Controlling and Managing Interest Rate. New Jersey, NJ: Prentice Hall.

Cornyn, A. G., \& Mays, E. (1997). Interest Rate Risk Models: Theory and Practice. Chicago, IL: Glenlake Publishing.

Coyle, B. (2016). Introduction to Interest-rate Risk. Financial World Publishing, London, England.

Deutsche Bundesbank, Ed. (2004). Monthly Report - September 2004, Volume 56, No 9. Frankfurt am Main, Germany.

Deutsche Bundesbank, Ed. (2006). Financial Stability Review 2006. Frankfurt am Main, Germany.

Deutsche Bundesbank, Ed. (2014). Financial Stability Review 2014. Frankfurt am Main, Germany.

Deutsche Bundesbank, Ed. (2016). Financial Stability Review 2016. Frankfurt am Main, Germany.

Deutsche Bundesbank, Ed. (2017). Financial Stability Review 2017. Frankfurt am Main, Germany.

Dietrich, A., \& Wanzenried, G. (2014). The determinants of commercial banking profitability in low-, middle-, and highincome countries. The Quarterly Review of Economics and Finance, 54, 337-354.

https://doi.org/10.1016/j.qref.2014.03.001

English, W. (2002). Interest rate risk and bank net interest margins. BIS quarterly review, December 2002, p. 67-82.

European Banking Authority, Ed. (2016). 2016 EU-WIDE STRESS TEST. London, England.

Genay, H., \& Podjasek, R. (2014). What is the impact of a low interest rate environment on bank profitability? Chicago 
Fed Letter No. 324.

Grumball, C. (1987). Managing Interest Rate Risk. New York, NY: Quorum Books.

Gup, B. E., \& Brooks, R. (1993). Interest Rate Risk Management: The Banker's Guide to Using Futures, Options, Swaps and Other Derivative Instruments. Chicago, IL: Bankers Publishing Company.

IMF (2011). Germany - Financial Sector Stability Assessment. IMF Country Report No. 11/169, Washington, USA.

Kaas, R., Goovaerts, M., Dhaene, J., \& Denuit, M. (2008). Modern Actuarial Risk Theory: Using R. 2. Edition, Berlin Heidelberg, Germany, Springer-Verlag. https://doi.org/10.1007/978-3-540-70998-5

Kroon, G. (2009). Messung und Steuerung von Kreditrisiken: Empirischer Befund und Handlungsempfehlungen. Wiesbaden, Germany, GWV Fachverlage. https://doi.org/10.1007/978-3-8349-8358-9

Laitinen, E. K. (2006). Partial Least Squares Regression in Payment Default Prediction. Investment Management and Financial Innovations, 3(1), 64-77.

Lichtner, J. (2017). Strategie-/Handlungsoptionen deutscher Sparkassen im Kontext eines Zinsanstiegs und Basel III: Ein bilanzanalytisches Simulationsmodell. Chemnitz, Germany: Dissertation at Technical University Chemnitz.

Maddala, G. S. (2017). Econometrics. Auckland, Australia: McGraw-Hill Education.

Memmel, C. (2008). Which interest rate scenario is the worst for a bank? Evidence from a tracking bank approach for German savings and cooperative banks. Frankfurt am Main, Germany: Deutsche Bundesbank, Discussion Paper, Series 2: Banking and Financial Studies, No. 07/2008.

Menningen, M. (2013). Aufbau, Bestandteile und Problemfelder ökonomischer Risikotragfähigkeit in Banken. Hamburg, Germany, Diplomica Verlag.

Miller, R. (2017). Can the Fed Unwind Without Unnerving Markets? www.bloomberg.com, Excerpt of the article dated 20th September 2017. Retrieved July 7, 2018, from www.bloomberg.com/news/articles/2017-09-20/can-the-fed-unwind-without-unnverving-markets-quicktake-q-a

Nawalkha, S. K., \& Chambers, D. R. (1999). Interest rate risk measurement and management. New York, NY: Institutional Investor.

Samuelson, P. A. (1945). The Effect of Interest Rates Increases on the Banking System. The American Economic Review, $35(1), 16-27$.

Schendera, C. F. G. (2014). Regressionsanalyse mit SPSS. 2. Edition, München, Germany, Oldenbourg Wissenschaftsverlag. https://doi.org/10.1524/9783110362527

Schlittgen, R. (2013). Regressionsanalysen mit R. München, Germany: Oldenbourg Wissenschaftsverlag. https://doi.org/10.1524/9783486739671

Scholz, H., Simon, S., \& Wilkens, M. (2007). Maturity transformation strategies and interest rate risk of financial institutions: Evidence from the German market. SSRN Working Paper. https://doi.org/10.2139/ssrn.1002965

Spellmann, F. (2002). Gesamtrisiko-Messung von Banken und Unternehmen. Wiesbaden, Germany, Deutscher Universitäts-Verlag. https://doi.org/10.1007/978-3-663-08108-1

Stephens, J. J. (2002). Managing Interest Rate Risk: Using Financial Derivatives. West Sussex, England: Wiley.

Wearden, G. (2018). ECB to end QE in December, but keep rates at record lows - as it happened. www.theguardian.com, excerpt of the article dated June 14, 2018. Retrieved July 7, 2018, from www.theguardian.com/business/live/2018/jun/14/ecb-qe-stimulus-mario-draghi-fed-rate-hike-uk-retail-salesbusiness-live

Wu, J. (2014). Research on Several Problems in Partial Least Squares Regression Analysis. The Open Electrical \& Electronic Engineering Journal, 8, 754-758. https://doi.org/10.2174/1874129001408010754

Yeniay, Ö., \& Göktas, A. (2002). A comparison of partial lest squares regression with other prediction methods. Hacettepe Journal of Mathematics and Statistics, 31(2002), 99-111.

Zagst, R. (2002). Interest-Rate Management. Berlin, Heidelberg, Germany: Springer-Verlag. https://doi.org/10.1007/978-3-662-12106-1

\section{Copyrights}

Copyright for this article is retained by the author(s), with first publication rights granted to the journal.

This is an open-access article distributed under the terms and conditions of the Creative Commons Attribution license which permits unrestricted use, distribution, and reproduction in any medium, provided the original work is properly cited. 